\title{
Genetic and morphological diversity of Trisetacus species (Eriophyoidea: Phytoptidae) associated with coniferous trees in Poland: phylogeny, barcoding, host and habitat specialization
}

\author{
Mariusz Lewandowski • Anna Skoracka • Wiktoria Szydło • \\ Marcin Kozak • Tobiasz Druciarek • Don A. Griffiths
}

Received: 31 October 2013/Accepted: 15 March 2014/Published online: 8 April 2014

(C) The Author(s) 2014. This article is published with open access at Springerlink.com

\begin{abstract}
Eriophyoid species belonging to the genus Trisetacus are economically important as pests of conifers. A narrow host specialization to conifers and some unique morphological characteristics have made these mites interesting subjects for scientific inquiry. In this study, we assessed morphological and genetic variation of seven Trisetacus species originating from six coniferous hosts in Poland by morphometric analysis and molecular sequencing of the mitochondrial cytochrome oxidase subunit I gene and the nuclear D2 region of $28 \mathrm{~S}$ rDNA. The results confirmed the monophyly of the genus Trisetacus as well as the monophyly of five of the seven species studied. Both DNA sequences were effective in discriminating between six of the seven species tested. Host-dependent genetic and morphological variation in $T$. silvestris and $T$. relocatus, and habitat-dependent
\end{abstract}

M. Lewandowski $(\bowtie) \cdot$ T. Druciarek

Department of Applied Entomology, Faculty of Horticulture, Biotechnology and Landscape

Architecture, Warsaw University of Life Sciences (SGGW), Nowoursynowska 159,

02-776 Warsaw, Poland

e-mail: mariusz_lewandowski@sggw.pl

T. Druciarek

e-mail: tobiasz_druciarek@sggw.pl

A. Skoracka · W. Szydło

Department of Animal Taxonomy and Ecology, Faculty of Biology, Adam Mickiewicz University, Umultowska 89, 61-614 Poznan, Poland

e-mail: anna.skoracka@amu.edu.pl

W. Szydło

e-mail: wiktoria.szydlo@amu.edu.pl

M. Kozak

Department of Botany, Faculty of Agriculture and Biology, Warsaw University of Life Sciences (SGGW), Nowoursynowska 159, 02-776 Warsaw, Poland

e-mail: nyggus@gmail.com

D. A. Griffiths

Agrobio, La Mojonera, Almería, Spain

e-mail: griffithsacari@aol.com 
genetic and morphological variation in T. juniperinus were detected, suggesting the existence of races or even distinct species within these Trisetacus taxa. This is the first molecular phylogenetic analysis of the Trisetacus species. The findings presented here will stimulate further investigations on the evolutionary relationships of Trisetacus as well as the entire Phytoptidae family.

Keywords Cryptic species - Genetic variation - Host specificity · Morphological variation $\cdot$ mtDNA COI $\cdot 28 \mathrm{~S}$ rDNA

\section{Introduction}

Mites belonging to the genus Trisetacus (Acari: Eriophyoidea: Phytoptidae) are associated with coniferous plants of the families Cupressaceae, Pinaceae and Taxodiaceae, and are widely distributed in Asia, Europe and North America (Xue et al. 2007; Castagnoli et al. 2010; Wang et al. 2012). Coniferous host plants inhabited by these mites are significant in forestry and as ornamental trees, thus many Trisetacus species are considered to be serious and economically important pests. They can cause chlorosis, browning, formation of rosette galls (resulting in distorted and stunted needles), cortical galls, inhibition of bud development, as well as destruction of seeds (Castagnoli 1996). Some Trisetacus species attack berries and destroy their seeds (Shevchenko 1962) or cause serious damage in nurseries and young stands of cypress (Simoni et al. 2004). The most serious damage is observed when mites occur in large colonies, and mass outbreaks of Trisetacus species in forests have been reported (Kruel 1963; Keifer and Saunders 1972; Styer et al. 1972; Shevchenko 1995; Marshall and Clayton 2004). In view of the economic importance of Trisetacus mites, damage control and management is imperative, which requires an improvement in the taxonomy of this group (Hoy 2011).

Many coniferous plants provide stable microhabitats in which Trisetacus mites proliferate. The evergreen habit and long life span of coniferous trees and their frequent occurrence in monocultures facilitate Trisetacus mite dispersal and availability of young tissues on which these eriophyoids feed (Boczek and Shevchenko 1996). The genus Trisetacus belongs to the putatively primitive family Phytoptidae (Boczek and Shevchenko 1996; Lindquist 1996), whose members possess some morphological traits that have been recently found in the oldest eriophyoid fossils in Triassic amber (Schmidt et al. 2012). The discovery of eriophyoids in Triassic amber established conifer feeding as an ancestral trait (Schmidt et al. 2012). Thus, high specialization of Trisetacus mites on conifers may support their primitive status. It has been found that if insects have elements of conservatism in their food-plant family preferences it can be expected that ancient and phylogenetically basal groups of phytophagous insects are more likely to be associated with ancient plant groups (Ward et al. 2003).

Trisetacus species have evolved different associations with their host plants. Many of them use various shelters like buds, seeds, needle sheaths, and bud scales, while others can induce gall formations. Some species have been recorded as vagrants, spending their lives wandering about on needles or twigs (Smith 1984; Castagnoli et al. 2010). However, it has been hypothesized that wanderers in fact may be shelter-associated mites collected during migrations between shelters (Castagnoli 1996). As such, the habitat of some Trisetacus species may have been incorrectly described. Some species have been reported as 
inhabiting more than one type of microhabitat. For example, Trisetacus juniperinus (Nalepa) has been found inside buds (causing needle agglomeration, enlargement and necrosis), galls (Jeppson et al. 1975; Łabanowski and Soika 2000; Castagnoli et al. 2010), or inhabiting berries (M. Lewandowski, personal observations). Such habitat differentiation in $T$. juniperinus may suggest that populations occurring in buds and those making galls are distinct, cryptic species (Bouneb et al. 2014; J. Amrine, personal communication). The existence of host races or cryptic species, as has been found in other eriophyoid species (e.g. Skoracka and Dabert 2010; Miller et al. 2013), is therefore suspected in the association of some Trisetacus species with several host plants (e.g. T. relocatus, T. silvestris). Variability in host or habitat use in parasites or herbivores has often been explained by the presence of cryptic species that exhibit narrower microhabitat preference or host range (e.g. Hebert et al. 2004; Steinauer et al. 2007; Johnson et al. 2012). Microhabitat and host specificity have been proposed to play a large role in the speciation of organisms because specialization promotes speciation by reducing gene flow (Futuyma and Moreno 1988; Brooks and McLennan 1993).

The existence of cryptic diversity may confound the taxonomy of a taxon of interest (Bickford et al. 2007). To understand the phylogeny and systematics of the genus Trisetacus as well as the family Phytoptidae, which is regarded as a paraphyletic group based almost entirely on plesiomorphic characters, an integrative approach combining morphological and molecular data should be useful (Lindquist and Amrine 1996; de Lillo and Skoracka 2010; Navajas and Navia 2010). Until now, only a few morphometric analyses have been applied to phylogenetic studies of Eriophyoidea (Hong and Zhang 1996a, b, 1997), and few studies have assessed intraspecific variation in Eriophyoidea, including host-adapted strains or cryptic species (Skoracka et al. 2002; Navia et al. 2006; Skoracka and Kuczyński 2006; Magud et al. 2007; Vidović et al. 2010). In recent years, molecular sequence data have become more available to study population genetics, taxonomy, systematics, and evolutionary trends of many acarine groups, including members of the Eriophyoidea (Fenton et al. 1996, 1997, 2000; Kumar et al. 1999, 2001; Navajas and Fenton 2000; Carew et al. 2004, 2009; Lemmetty et al. 2004; Navia et al. 2005; Goolsby et al. 2006; de Lillo and Skoracka 2010; Skoracka and Dabert 2010; Skoracka et al. 2012, 2013, 2014; Miller et al. 2012, 2013). However, we are not aware of any study on phytoptid mites using an integrated morphometric and molecular approach. Among the 644 nuclear and mitochondrial nucleotide sequences obtained for Eriophyoidea and deposited in the GenBank database (Benson et al. 2005), only three represent phytoptid mites, one of which is T. juniperinus (http://www.ncbi.nlm.nih.gov/ accessed 22nd October 2013). The combination of genetic and morphological characters to study evolutionary relationships within the genus Trisetacus should assist in understanding mite-host relationships and phylogenetic relatedness of species, thereby improving our understanding of Phytoptidae biology, taxonomy and systematics. Discriminating species, especially pest species, is crucial for the development of effective management strategies (Bickford et al. 2007). The misidentification of economically important species hidden within cryptic complexes may lead to serious negative consequences, such as inappropriate diagnoses of parasites and pathogens and ineffective control efforts against pests and invasive species (Armstrong and Ball 2005; Pringle et al. 2005; Bickford et al. 2007).

In this study we link morphometric and molecular techniques in order to examine host and habitat specificity of Trisetacus species, viz. T. juniperinus, T. laricis (Tubeuf), T. piceae (Roivainen), T. pini, T. quadrisetus (Thomas), T. relocatus Bagnyuk \& Shevtchenko, and T. silvestris Castagnioli. Specifically we have examined: (1) phylogenetic relationships and interspecific variation within the Trisetacus genus, (2) host and habitat 
specialization of Trisetacus species, and (3) the efficiency of two genetic markers (subunit I of the mitochondrial cytochrome c oxidase gene [COI] and D2 region of $28 \mathrm{~S}$ rDNA) for barcoding Trisetacus species.

\section{Materials and methods}

\section{Sampling}

The study included 31 populations of Trisetacus species collected from different host plants and microhabitats, and various locations in Poland (Table 1). Mite populations from individual localities, involving collections from the same host, were always gathered from plants 20-400 m apart. Mites were collected from six coniferous species (Pinopsida) belonging to two families, including species important in forestry and ornamental plant nurseries, namely: common juniper, Juniperus communis L. (Cupressaceae); European larch, Larix decidua Mill.; Norway spruce, Picea abies (L.) H.Karst.; Scots pine, Pinus sylvestris L.; mountain pine, Pinus mugo Turra; and silver fir, Abies alba Mill. (Pinaceae).

Samples were collected between 2006 and 2011. A single sample consisted of a $15 \mathrm{~cm}$ shoot tip, including side shoots collected from the particular host plant and locality (see sample codes in Table 1). Samples were transported to the laboratory, where mite specimens were collected by direct inspection with a stereomicroscope and mounted on slides following standard protocol (Amrine and Manson 1996; de Lillo et al. 2010). Mounted mites were identified as described by Tubeuf (1897), Nalepa (1911), Castagnoli (1973), Jeppson et al. (1975), Bagnyuk (1976), Bagnyuk and Shevtchenko (1982), Keifer et al. (1982), Łabanowski and Soika (2000), and Amrine et al. (2003). One to 60 mite specimens of a given species collected from the majority of samples (see sample codes in Table 1) were placed in labelled 1.5-ml microcentrifuge tubes with $180 \mu \mathrm{l}$ of ATL buffer (Qiagen, Hilden, Germany) and frozen for further molecular analyses.

Molecular study

\section{DNA extraction, amplification and sequencing}

Pooled samples of one to 60 mite specimens stored in ATL buffer were processed as one DNA sample for DNA extraction (Table 1). Isolations were made using a non-destructive method described by Dabert et al. (2008). The voucher specimens are stored in the reference collection of the Department of Animal Taxonomy and Ecology, AMU, Poznań, Poland. To eliminate concern about possible multiple operational taxonomic units within DNA samples extracted from multiple specimens, the precautions described by Skoracka et al. (2012) and Skoracka et al. (2013) were taken. The same DNA samples after extractions were used for amplification of COI and D2 gene fragments.

The cytochrome oxidase subunit I (COI) gene fragment (covering ca. $670 \mathrm{bp}$ of the $5^{\prime}$ terminus of COI gene) was amplified by polymerase chain reaction (PCR) using the degenerate primers bcdF01 and bcdR04 (Skoracka and Dabert 2010). The PCR was carried out in $10 \mu \mathrm{l}$ reaction volumes containing $5 \mu \mathrm{l}$ Type-it Multiplex PCR Master Mix (Qiagen), 10 pmol of each primer and $4 \mu$ of DNA template. Amplification of the D2 region of 28S rDNA was performed with the primers D1D2fw2 (Sonnenberg et al. 2007) and 28Sr0990 (Mironov et al. 2012) with the same reaction volume and substrate proportions like COI fragment except that 5 pmol of each primer was used. The thermo-cycling profile 


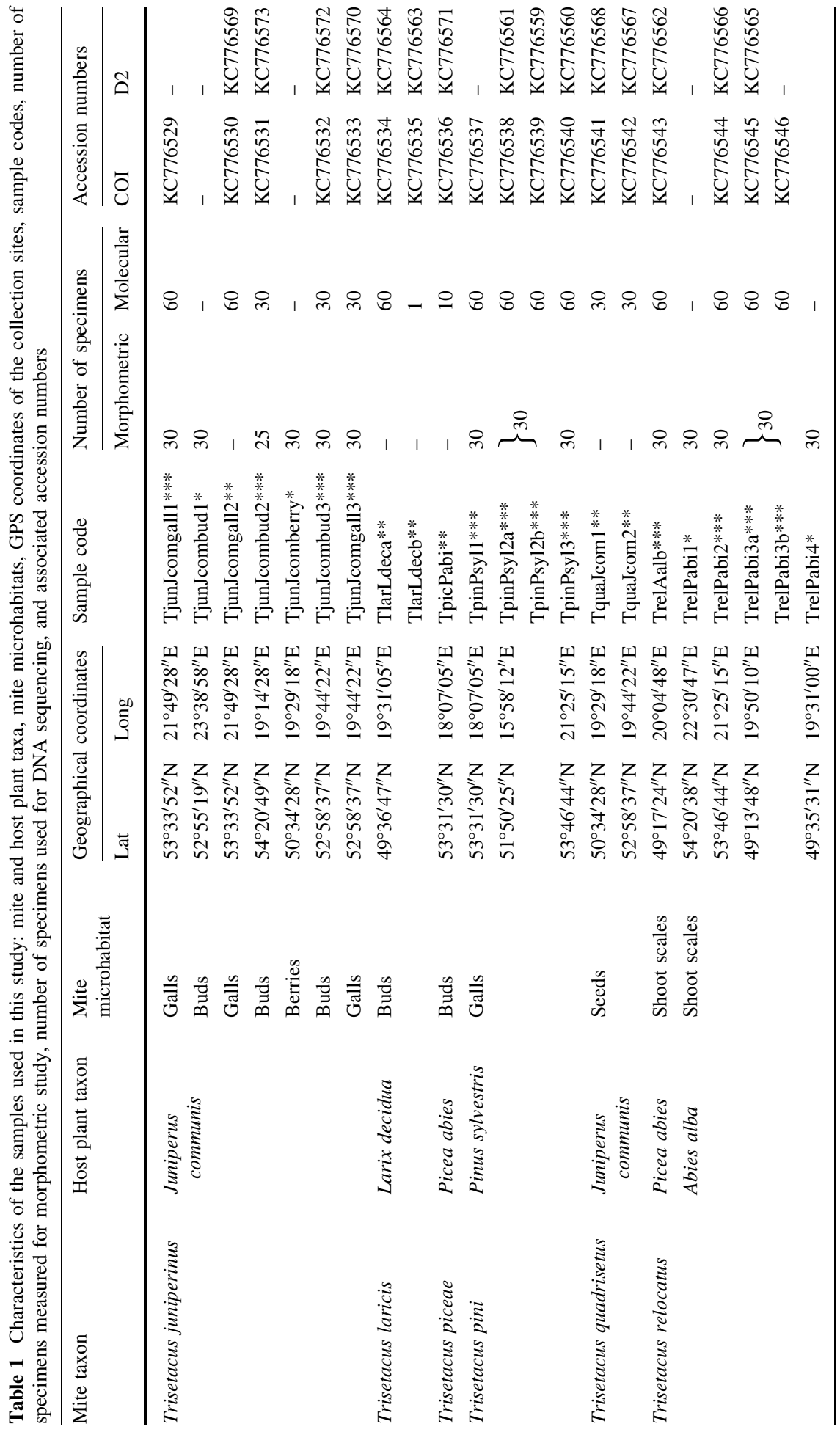




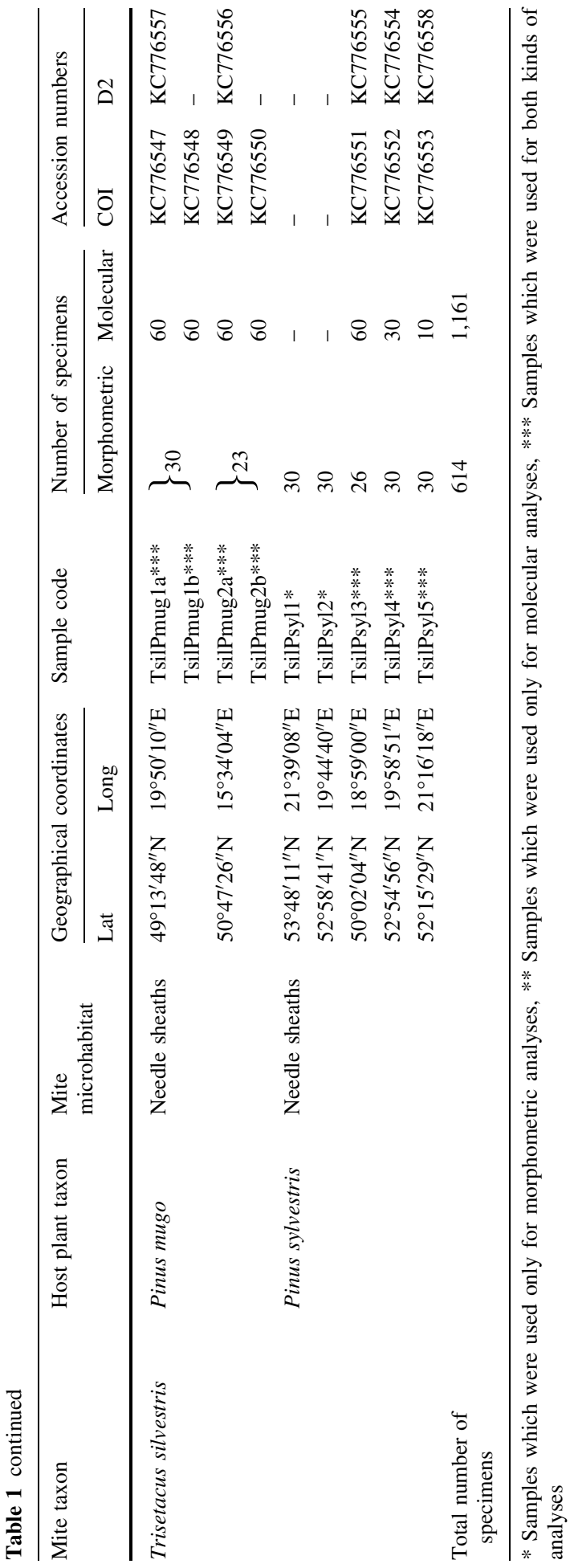


of both reactions consisted of one cycle of initial denaturation for $5 \mathrm{~min}$ at $95{ }^{\circ} \mathrm{C}$, followed by 35 cycles of denaturation for $30 \mathrm{~s}$ at $95{ }^{\circ} \mathrm{C}$, annealing for $30 \mathrm{~s}$ at $50{ }^{\circ} \mathrm{C}$, and extension for $1 \mathrm{~min}$ at $72{ }^{\circ} \mathrm{C}$; with a final strand extension of $15 \mathrm{~min}$ at $72{ }^{\circ} \mathrm{C}$. After amplification, $3 \mu \mathrm{l}$ of the PCR product was diluted two-fold with distilled water and analysed by electrophoresis in a $1 \%$ agarose gel. Samples containing visible bands were directly sequenced in both directions using $1 \mu \mathrm{l}$ of the PCR product and $50 \mathrm{pmol}$ of the corresponding sequencing primer (viz. bcdF01 and bcdR04 for COI sequences, and D1D2fw2 and 28Sr0990 for D2 sequences). Sequencing was performed with BigDye Terminator v3.1 using the manufacturer's protocol and products of the sequencing reaction were analyzed with an ABI Prism 3130XL or 3730 Analyzer (Applied Biosystems, Foster City, CA, USA). Trace files were checked and edited using MEGA5 (Tamura et al. 2011). All sequences have been deposited in the GenBank under the accession numbers indicated in Table 1.

\section{Sequence and phylogenetic analyses}

Nalepella brewerianae Domes 2005 (Phytoptidae) (GenBank accession numbers: KJ410020 for mtDNA COI and KJ410021 for 28S rDNA D2) was chosen as an outgroup species for molecular analyses. The COI and D2 sequences were aligned separately by CLUSTAL W using MEGA5 (Tamura et al. 2011) with default gap weighing parameters, followed by manual adjustment. Alignment of the COI sequences covering $605 \mathrm{bp}$ wastranslated into amino acids to exclude the presence of pseudogenes or stop codons. The uncorrected pairwise genetic distances (\%) were calculated using MEGA5 (Tamura et al. 2011). This simple distance measure was implemented to achieve reliable estimates of both intra- and interspecific genetic variation. Standard error estimates were obtained using a bootstrap procedure (1,000 replicates).

The best-fit models of nucleotide substitution were selected with jModelTest ver. 2 (Darriba et al. 2012; Guindon and Gascuel 2003) based on likelihood scores for 88 different models, Akaike Information Criterion (AIC) and Bayesian Information Criterion (BIC). Two analyses were performed for the COI data set; one analysis (complete) included all sequences available, while the second analysis (reduced) included sequences obtained for mite populations that were also analysed morphologically (see Table 1). The result of the second analysis was used to graphically compare the genetic and morphological variation between and within Trisetacus species. For the complete COI data set, TIM1 + I + G (Posada 2003) was chosen as the model for the maximum likelihood (ML) analysis according to AIC, where the proportion of invariable sites ( $\mathrm{p}$-inv) $=0.4160$ and the gamma distribution shape parameter $(\mathrm{G})=1.0680$. The estimated base frequencies were: $\mathrm{A}=0.2061, \mathrm{C}=0.1209, \mathrm{G}=0.1540$ and $\mathrm{T}=0.5190$ and substitution rates were $[\mathrm{AC}]=1.0,[\mathrm{AG}]=12.6865,[\mathrm{AT}]=2.8725,[\mathrm{CG}]=2.8725,[\mathrm{CT}]=7.0961,[\mathrm{GT}]=$ 1.0. The GTR $+\mathrm{I}+\mathrm{G}$ model (Rodriguez et al. 1990) was chosen for the Bayesian inference of phylogeny (BI) for the COI complete data. Estimated base frequencies were: $\mathrm{A}=0.2008, \mathrm{C}=0.1306, \mathrm{G}=0.1572$, and $\mathrm{T}=0.5115$, with substitution rates $[\mathrm{AC}]=$ 0.9710, $[\mathrm{AG}]=12.2072,[\mathrm{AT}]=3.1656,[\mathrm{CG}]=1.6401,[\mathrm{CT}]=6.0245,[\mathrm{GT}]=1.0$, the proportion of invariable sites was $(\mathrm{p}$-inv) $=0.4230$ and the gamma distribution shape parameter was $(G)=1.23$. For the reduced data set only BI analysis was performed using HKY + I + G model (Hasegawa et al. 1985), where the transition/transversion ratio was $(\mathrm{ti} / \mathrm{tv})=2.3349$ the proportion of invariable sites $(\mathrm{p}$-inv) $=0.4440$ and the gamma distribution shape parameter $(\mathrm{G})=1.0120$. The estimated base frequencies were: $\mathrm{A}=0.2101, \mathrm{C}=0.1241, \mathrm{G}=0.1599$ and $\mathrm{T}=0.5059$. 
For the D2 28S rDNA data set, the HKY + G substitution model (Hasegawa et al. 1985) was chosen according to BIC, with the following estimated base frequencies: $\mathrm{A}=0.2621, \mathrm{C}=0.1649, \mathrm{G}=0.2453$, and $\mathrm{T}=0.3277$. The transition/transversion ratio was $(\mathrm{ti} / \mathrm{tv})=3.1457$ and the gamma distribution shape parameter was $(\mathrm{G})=0.4030$. The TPM3uf + G model (Kimura 1981; Posada 2008) was selected according to AIC. Estimated base frequencies were: $\mathrm{A}=0.2626, \mathrm{C}=0.17121, \mathrm{G}=0.2460$, and $\mathrm{T}=0.3202$, substitution rates $[\mathrm{AC}]=[\mathrm{CG}]=0.5023,[\mathrm{AG}]=[\mathrm{CT}]=5.4107$ and $[\mathrm{AT}]=[\mathrm{GT}]=$ 1.0 and the gamma distribution shape parameter was $(\mathrm{G})=0.4050$.

For the combined analysis COI and D2 sequences were concatenated for the mite populations, where COI fragment covered from 1 to 605 nucleotides, and D2 from 606 to 1,262 nucleotides. The BI analysis was performed with the same models as for the separate data sets (i.e. GTR + I + G model for COI partition and HKY + G model for D2 partition). Estimated base frequencies for the GTR $+\mathrm{I}+\mathrm{G}$ were: $\mathrm{A}=0.2008, \mathrm{C}=0.1306$, $\mathrm{G}=0.1572, \mathrm{~T}=0.5115$, proportion of invariable sites $(\mathrm{p}-\mathrm{inv})=0.4240$, gamma distribution shape parameter $(\mathrm{G})=1.2310$, and the substitution rates $[\mathrm{AC}]=0.9720,[\mathrm{AG}]=$ $12.2130,[\mathrm{AT}]=3.1675,[\mathrm{CG}]=1.6411,[\mathrm{CT}]=6.0256$ and $[\mathrm{GT}]=1.0$. The parameters of HKY $+\mathrm{G}$ model were the same as to those for D2 dataset analysis.

Bayesian inference of phylogenetic relationships was performed with MrBayes v.3.2 (Ronquist et al. 2012). For each dataset, two independent runs were performed and each consisted of four chains with a number of generations developed until the average standard deviation of split frequencies was less than 0.01 . A $50 \%$ majority consensus trees with posterior probability values was composed out of obtained trees, after excluding the first $25 \%$ of trees produced in the analyses. Maximum likelihood analyses were performed with PhyML 3.0 (Guindon et al. 2010). Analyses were set to optimize branch lengths and the tree topology search method used a nearest neighbour interchange algorithm. For each ML analysis, the Approximate Likelihood Ratio Test (aLRT) (Anisimova and Gascuel 2006) was performed.

\section{Morphometric study}

Sample codes of the Trisetacus populations studied morphologically are labelled in Table 1. Twenty-three to 30 females from each population were examined in the dorsoventral position using a phase-contrast microscope. Twenty-seven morphological traits of each individual were measured with the Soft Imaging System Cell D (Fig. 1).

Discriminant analysis (Krzanowski 2000) was used to explain the variability in the morphology of individuals between various populations inhabiting a particular host taxon (differentiated by locality and microhabitat). The analysis was conducted separately for the four Trisetacus taxa (T. juniperinus, T. pini, T. relocatus and T. silvestris). This method takes into account the grouping structure due to populations, and helps one to find similar/ dissimilar individuals. The values of each trait were first standardized to have mean 0 and variance 1, so that all traits had the same weight in the analysis. The analysis was carried out using the MASS package (Venables and Ripley 2002) in R (R Development Core Team 2013).

Hierarchical cluster analysis was then employed to group the mite populations (described in Table 1) on the basis of their morphology. We used samples for which both morphometric and genetic data were available. The analysis was performed on population mean trait values, which were first standardized to have mean 0 and variance 1 . The agglomerative clustering algorithm was carried out using Manhattan distance and the unweighted pair-group average method (Kaufman and Rousseeuw 1990). 

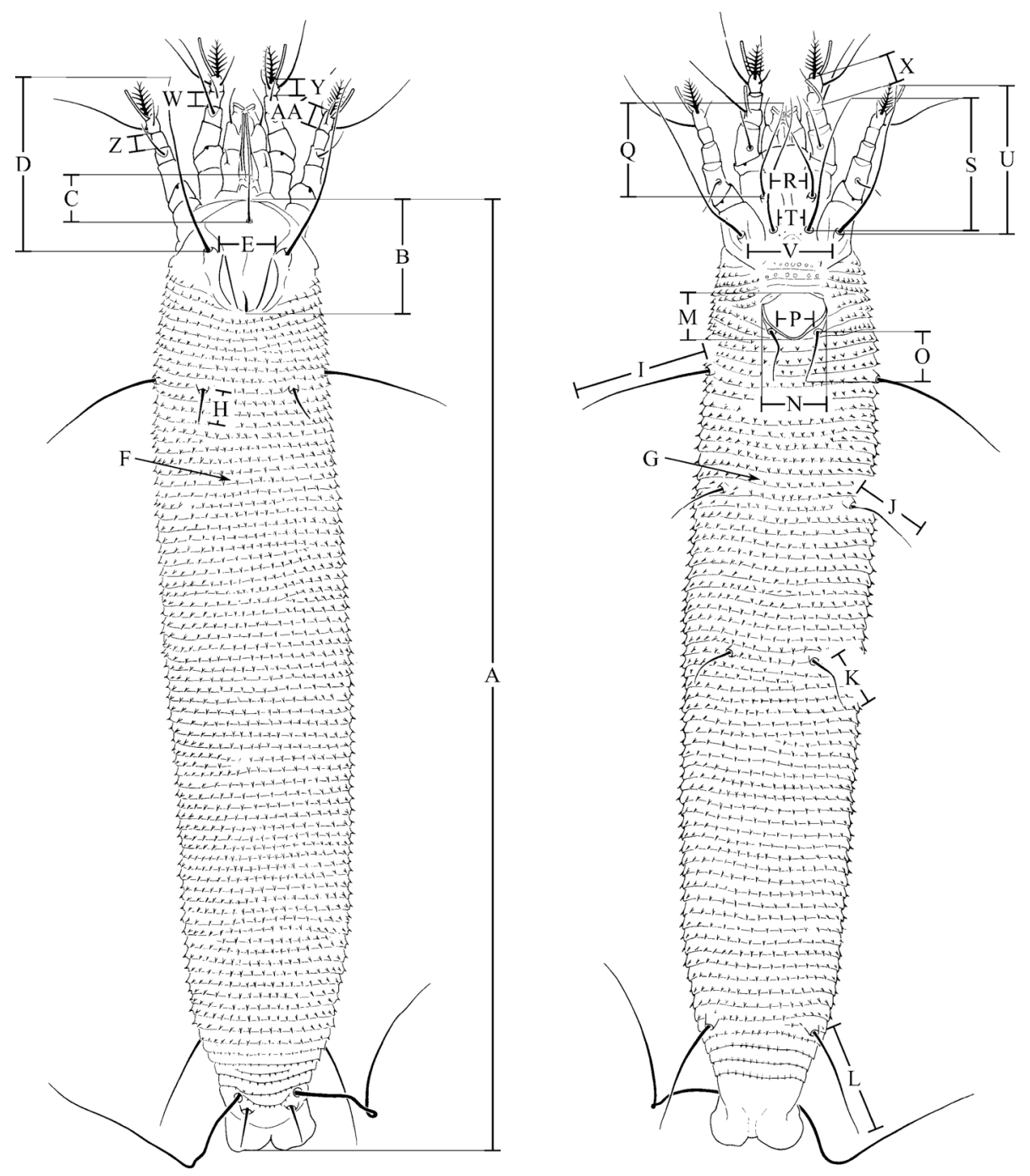

Fig. 1 Measurements of Trisetacus female morphology used in the morphometric analysis. Explanation of abbreviations: $A$ length of body, $B$ prodorsal shield length, $C$ length of seta $v i, D$ length of setae $s c$, $E$ tubercles $s c$ apart, $F$ no. of dorsal annuli, $G$ no. of ventral annuli, $H$ length of setae $c 1, I$ length of setae $c 2$, $J$ length of setae $d, K$ length setae of $e, L$ length of $f, M$ length of genitalia, $N$ width of genitalia, $O$ length of setae $3 a, P$ tubercles $3 a$ apart, $Q$ length of setae $1 b, R$ tubercles $1 b$ apart, $S$ length of setae $1 a, T$ tubercles $1 a$ apart, $U$ length of setae $2 a, V$ tubercles $2 a$ apart, $W$ length of tibia I, $X$ length of tibial solenidion, $Y$ length of tarsus I, $Z$ length of tibia II, $A A$ length of tarsus II

Voucher specimens of individual mites measured for the morphometric study are deposited in the reference collection of the Department of Applied Entomology, Faculty of Horticulture, Biotechnology and Landscape Architecture, Warsaw University of Life Sciences (SGGW), Poland. 


\section{Results}

Molecular analyses

\section{COI sequence diversity and phylogenetic analyses}

The final COI dataset consisted of 26 aligned sequences of $605 \mathrm{bps}$, representing 25 populations of Trisetacus species and one outgroup species. No insertions or deletions were found. In the alignment, 269 (44.5\%) sites were parsimony informative, and $301(49.7 \%)$ sites were variable. Nineteen haplotypes were identified from 25 COI sequences of Trisetacus species with clear correspondence to the host plant species or microhabitat. The average mean divergence over all the sequence pairs (including the outgroup taxon) was $20.6 \%(\mathrm{SE}=1.0 \%)$. Pairwise comparison of the COI distances within and between the Trisetacus species including outgroup species is given in Table 2.

General topologies of the phylogenetic trees inferred by Bayesian inference (BI) and maximum likelihood (ML) analyses of the nucleotide COI data set were similar and revealed similar structures thus, only the BI tree is presented. It strongly supported the monophyly of the Trisetacus genus (Fig. 2). There was also strong support for the monophyly of $T$. silvestris, which clustered separately from the other Trisetacus species. Populations of this species were variable and formed two different highly supported clades (distances between clades $=14.9 \% ; \mathrm{SE}=1.3 \%$ ), one containing Scots-pine-associated populations and the second comprising populations associated with mountain pine (Fig. 2). Analyses strongly supported the monophyly of $T$. juniperinus, $T$. quadrisetus, and $T$. pini. Populations of $T$. juniperinus were highly variable (intra-clade variation $11.9 \%$ ), with gall-associated populations forming a strongly supported clade, whereas bud-associated populations did not form a distinct clade (Fig. 2). Variation among bud-associated population was $17.2 \%(\mathrm{SE}=2)$. The distance between gall-associated and bud-associated populations was $16.5 \%(\mathrm{SE}=1.3)$. The relationships between $T$. relocatus, $T$. pini, $T$. piceae, and $T$. laricis were not resolved (polytomy). The monophyly of $T$. relocatus was not supported and host-associated populations of this species were highly variable, with $9.6 \%$ intra-species variation. Spruce-associated populations exhibited low variation $(0.6 \%, \mathrm{SE}=0.2)$ and clustered together with strong support. Fir-associated populations clustered to T. laricis as a sister lineage (Fig. 2). The divergence between host-associated populations of $T$. relocatus was greater $(18.6 \%, \mathrm{SE}=1.5)$ than the distance between firassociated population of $T$. relocatus and $T$. laricis $(17.1 \%, \mathrm{SE}=1.5)$.

\section{D2 sequence diversity and phylogenetic analyses}

The nuclear sequence data comprised 660 base pairs of the D2 region of the 28S rDNA from 21 Trisetacus populations and the outgroup species. The average mean divergence over all sequence pairs (including the outgroup taxa) was $14.6 \%(\mathrm{SE}=0.7 \%)$. Pairwise comparison of the distances within and between the D2 sequences of Trisetacus species including the outgroup species is presented in Table 3.

General topologies of the phylogenetic trees inferred by Bayesian inference (BI) and maximum likelihood (ML) analyses were similar and consistently revealed the same structure, thus only the BI data is presented. Similar to COI analyses, D2 analyses confirmed the monophyly of Trisetacus genus and five Trisetacus species with strong support, but did not confirm the monophyly of $T$. relocatus. Spruce-associated populations of T. relocatus clustered together in a highly supported clade, whereas fir-associated 
Table 2 Estimates of average divergence (shown as percentages with standard error estimates in parentheses) for mtDNA COI sequence pairs within (emboldened) and between Trisetacus species and the outgroup species

\begin{tabular}{lrrrrrrr}
\hline & T. silvestris & T. laricis & T. relocatus & T. piceae & T. pini & T. quadrisetus & T. juniperinus \\
\hline T. silvestris & $8.8(0.8)$ & & & & & & \\
T. laricis & $25.5(1.4)$ & $5.3(0.9)$ & & & & & \\
T. relocatus & $23.2(1.4)$ & $18.3(1.3)$ & $9.6(0.8)$ & & & & \\
T. piceae & $25.1(1.6)$ & $18.5(1.4)$ & $17.3(1.3)$ & $\mathrm{n} / \mathrm{c}$ & & & \\
T. pini & $25.4(1.6)$ & $19.2(1.5)$ & $18.3(1.4)$ & $19.0(1.5)$ & $0.1(0.1)$ & & \\
T. quadrisetus & $24.2(2.2)$ & $22.4(1.6)$ & $20.6(1.4)$ & $20.7(1.6)$ & $20.3(1.5)$ & $0.7(0.3)$ & \\
$\begin{array}{l}\text { T. juniperinus } \\
\text { Nalepella }\end{array}$ & $28.6(1.5)$ & $23.7(1.5)$ & $22.4(1.4)$ & $21.6(1.4)$ & $22.4(1.4)$ & $20.4(1.3)$ & $11.9(0.9)$ \\
$\quad$ brewerianae & $24.8(1.5)$ & $24.9(1.6)$ & $25.2(1.6)$ & $23.1(1.6)$ & $24.3(1.6)$ & $22.6(1.6)$ & $24.0(1.5)$ \\
\hline
\end{tabular}

T. relocatus clustered together with a T. laricis clade (Fig. 3). Divergence in the D2 gene among the host-associated populations of $T$. relocatus was higher $(3.7 \%, \mathrm{SE}=0.7)$ than the distance between fir-associated population of $T$. relocatus and $T$. laricis $(2.9 \%$, $\mathrm{SE}=0.6$ ). There was high variation in the D2 gene within T. juniperinus (Fig. 3), with divergence between gall-associated and bud-associated populations of $5.3 \%$ ( $\mathrm{SE}=0.7$ ). Host-dependent variation in T. silvestris in the D2 gene was not as evident as in the case of the mitochondrial COI gene. Populations from different pine species clustered together, although mountain pine-associated mites formed a well-supported internal clade (Fig. 3). Divergence between host-associated populations of $T$. silvestris was $0.3 \%$ ( $\mathrm{SE}=0.2$ ).

Combined analysis

The combined analysis, which included unique variants of nucleotide sequences of the mitochondrial cytochrome $c$ oxidase subunit I and nuclear D2 region of 28S, supported the results of single analyses indicating the monophyly of the genus Trisetacus, as well as five of the studied species (viz. T. silvestris, T. juniperinus, T. laricis, T. pini, T. quadrisetus). Moreover, the combined analysis corroborated the lack of monophyly for T. relocatus, and the sister relationships of fir-associated populations of this species to T. juniperinus. High host-associated and habitat-associated intra-species variation within $T$. silvestris and $T$. juniperinus, respectively, was also detected (Fig. 4).

Morphometric analyses

The discriminant analysis of 27 traits showed distinct variation between populations of three out of four examined species, viz. T. juniperinus, T. relocatus and $T$. silvestris (Fig. 5a, c, d). In contrast, there was an overlap of all three populations of $T$. pini relative to canonical variates (Fig. 5b).

Populations of $T$. juniperinus occurring in different microhabitats were significantly distinct from one another, with one exception, viz. the bud-inhabiting population TjunJcombud 2 was found to cluster with the berry-associated population (TjunJcomberry) (Fig. 5a). The first canonical variate (explaining $57.4 \%$ of the total variation) clearly separated these last two populations from the other four populations. Individuals from these two populations were characterized by longer opisthosomal setae $d(\mathrm{~J})$ and 


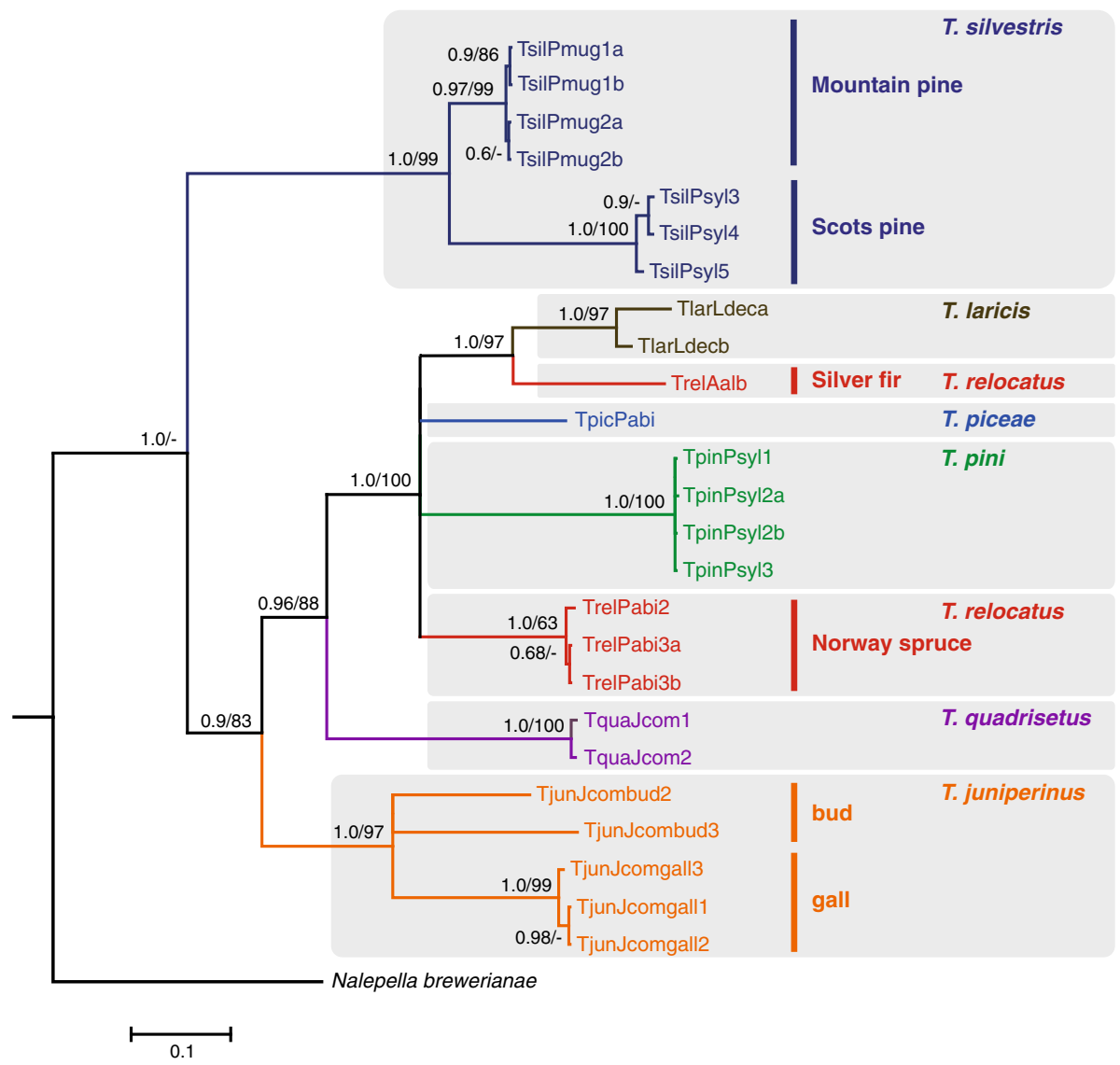

Fig. 2 Bayesian inference (BI) tree constructed using the GTR $+\mathrm{I}+\mathrm{G}$ model on data from the cytochrome c oxidase subunit I sequences of Trisetacus and an outgroup species. Trisetacus species clades are color coded within grey boxes). Within $T$. silvestris, T. relocatus, and T. juniperinus, populations associated with different host plant species or habitats are indicated as vertical lines. Concordant tree was obtained by Maximum likelihood (ML) analysis, which produced the same topology in defining groups. Statistical supports indicate Bayesian posterior probabilities/maximum likelihood aLRT values. Only statistical supports greater than $0.6 / 60$ are indicated above branches

$e(\mathrm{~K})$ (Table 4). The second canonical variate, which showed $21.2 \%$ variation, separated bud-associated and gall-making populations (Fig. 5a). The distance between tubercles of scapular setae (E) and the length of opisthosomal setae $d(\mathrm{~J})$ contributed most to this discrimination.

The first canonical variate (identifying $64.2 \%$ of total variability) clearly separated the fir-inhabiting populations of $T$. relocatus from those inhabiting spruce (Fig. 5c). Firassociated individuals were characterized by longer setae $c l(\mathrm{H})$, a greater distance between tubercles of proximal setae on coxosternum II (V) and a shorter body length (Table 4). Spruce-associated populations of T. relocatus formed a clumped group with relatively low morphological variability. The exception was one northern population (TrelPabi1), in which the second canonical variate contributed to $20.6 \%$ of the total variation (Fig. 5c). Traits that distinguished this population were linked to body length (A), and lengths of tibial solenidion (X) and setae $c l(\mathrm{H})$ (Fig. 5c). 
Table 3 Estimates of average divergence (shown as percentages with standard error estimates in parentheses) for D2 region of 28S rDNA sequence pairs within (emboldened) and between Trisetacus species and the outgroup species

\begin{tabular}{lccccccc}
\hline & T. silvestris & T. laricis & T. relocatus & T. piceae & T. pini & T. quadrisetus & T. juniperinus \\
\hline T. silvestris & $0.2(0.1)$ & & & & & & \\
T. laricis & $10.1(1.2)$ & $0.3(0.2)$ & & & & & \\
T. relocatus & $9.4(1.1)$ & $3.9(0.6)$ & $2.5(0.5)$ & & & & \\
T. piceae & $10.4(1.2)$ & $5.6(0.8)$ & $4.8(0.7)$ & $\mathrm{n} / \mathrm{c}$ & & & \\
T. pini & $11.2(1.3)$ & $5.9(0.8)$ & $5.8(0.8)$ & $7.5(0.9)$ & $0.0(0.0)$ & & \\
T. quadrisetus & $11.9(1.3)$ & $14.7(1.4)$ & $14.6(1.4)$ & $15.5(1.4)$ & $15.5(1.5)$ & $0.0(0.0)$ & \\
$\begin{array}{l}\text { T. juniperinus } \\
\text { Nalepella }\end{array}$ & $18.1(1.5)$ & $18.7(1.5)$ & $18.6(1.4)$ & $20.7(1.5)$ & $21.0(1.5)$ & $21.7(1.6)$ & $4.5(0.6)$ \\
$\quad$ brewerianae & $38.8(2.2)$ & $38.4(2.2)$ & $38.8(2.2)$ & $38.7(2.2)$ & $37.0(2.2)$ & $40.0(2.2)$ & $40.5(2.0)$ \\
\hline
\end{tabular}

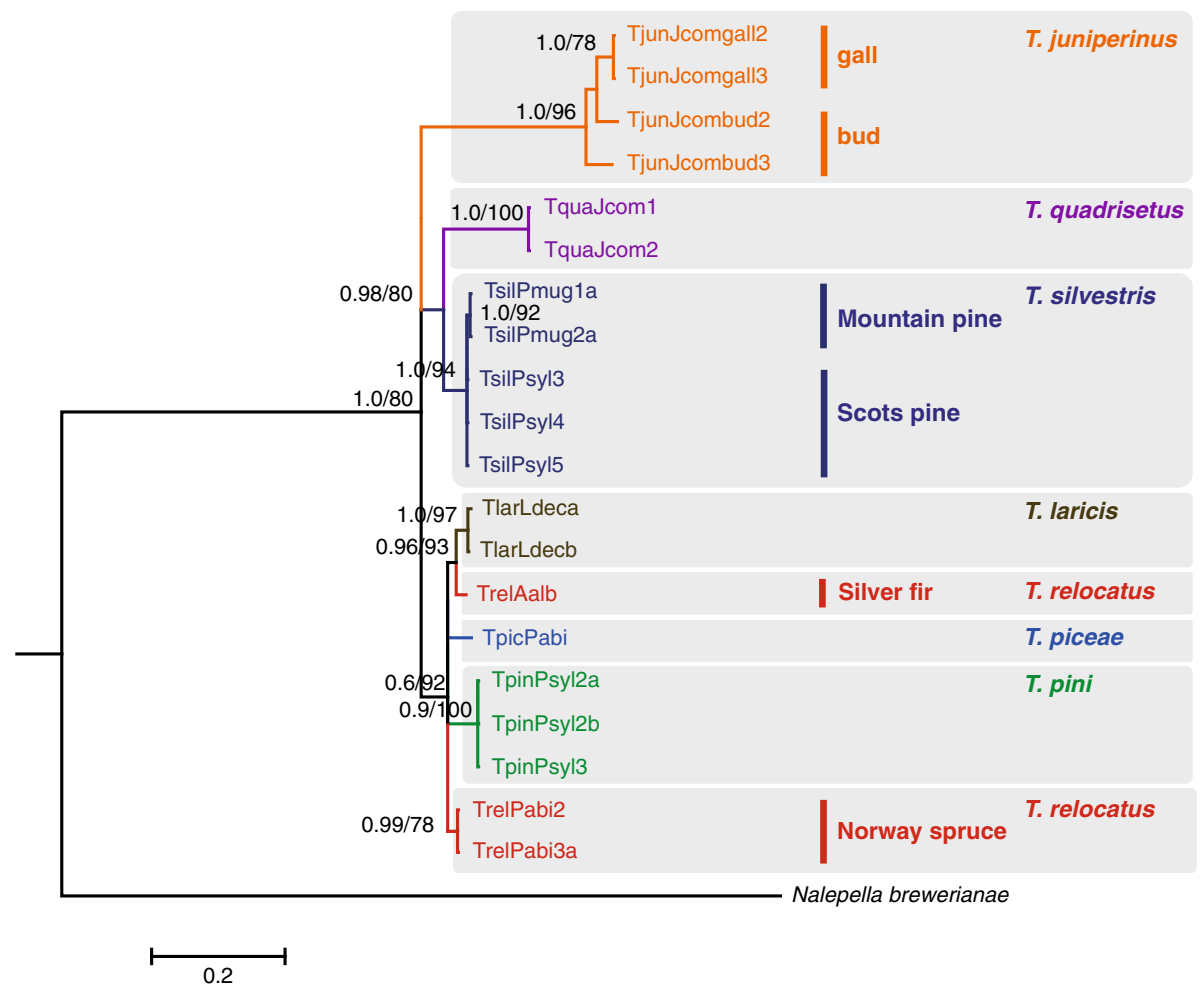

Fig. 3 Bayesian inference (BI) tree constructed using the HKY + G model on data from D2 region of 28S rDNA sequences of Trisetacus and an outgroup species. Trisetacus species clades are color coded within grey boxes. Within $T$. silvestris, $T$. relocatus, and T. juniperinus, populations associated with different host plant species or habitats are indicated as vertical lines. Concordant tree was obtained by Maximum likelihood (ML) analysis, which produced the same topology in defining groups. Statistical supports indicate Bayesian posterior probabilities/maximum likelihood aLRT values. Only statistical supports greater than $0.6 / 60$ are indicated above branches 


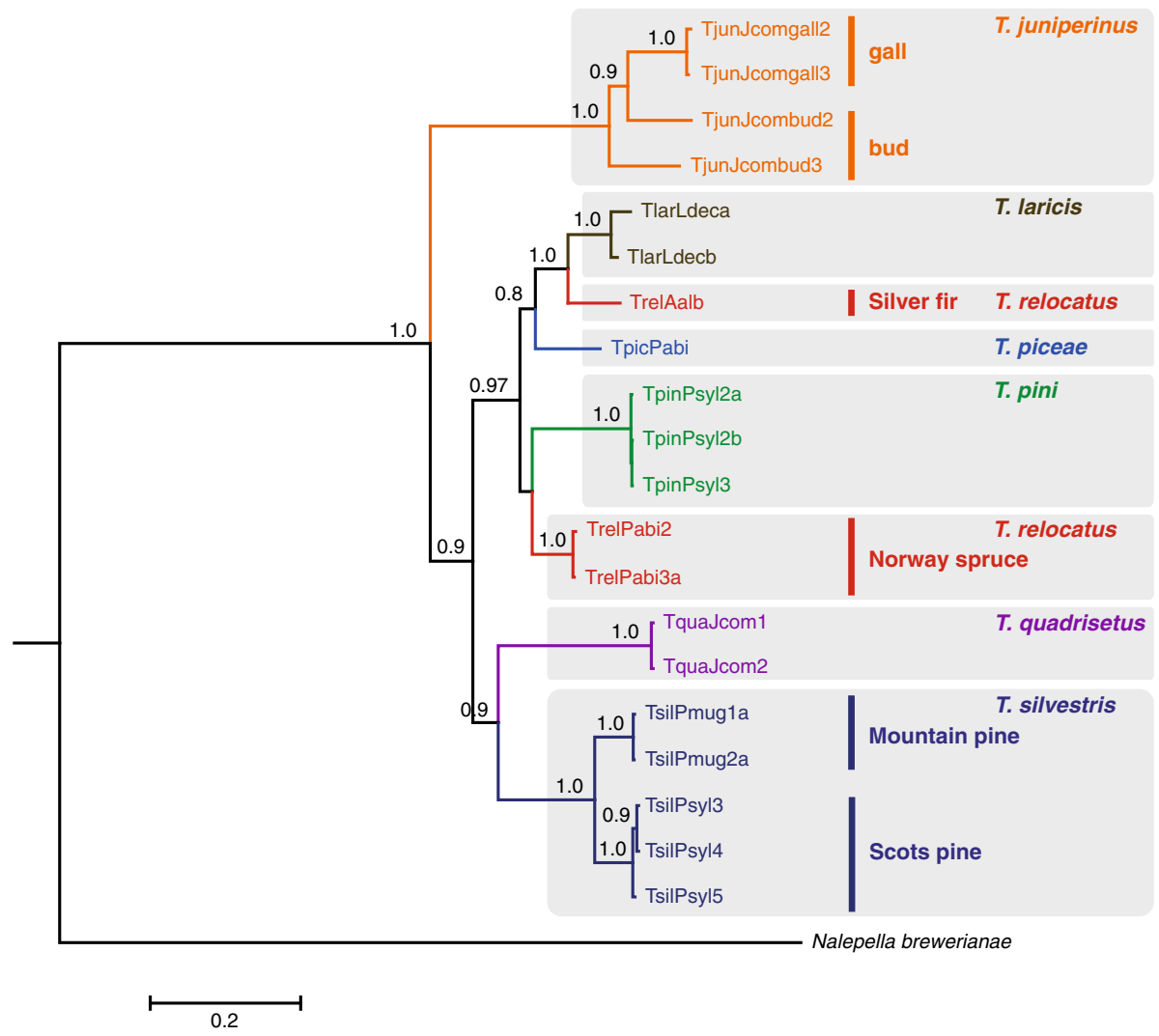

Fig. 4 Combined Bayesian inference (BI) tree calculated from the cytochrome c oxidase subunit I sequences (COI) and D2 region of 28S rDNA sequences of Trisetacus and an outgroup species. Trisetacus species are color coded within grey boxes. Within T. silvestris, T. relocatus, and T. juniperinus, populations associated with different host plant species or habitats are indicated as vertical lines. Statistical supports indicate Bayesian posterior probabilities. Only statistical supports greater than 0.6 are indicated above branches

The first canonical variate, describing $70.7 \%$ of the total variability, separated $T$. silvestris individuals inhabiting the host $P$. mugo from $T$. silvestris individuals associated with the host $P$. sylvestris (Fig. 5d). Individuals from $P$. mugo were characterized by wider genitalia $(\mathrm{N})$, a longer prodorsal shield (B) and shorter setae $c 1(\mathrm{H})$ (Table 4). Mites from $P$. mugo formed a single clade with no distinct differences between populations. The second canonical variate, describing $11.2 \%$ of the total variability, separated the population TsilPsyl5 from populations TsilPsyl4 and TsilPsyl3 (Fig. 5d), thus identifying a difference in body length (A) and length of setae $c l(\mathrm{H})$ between them.

Morphological and COI phylogenetic analyses

In general, morphological relationships among Trisetacus populations were similar to those revealed by the mtDNA COI, although some differences were observed (Fig. 6). First, the relationships between two host-associated clades of $T$. relocatus and the clade of 

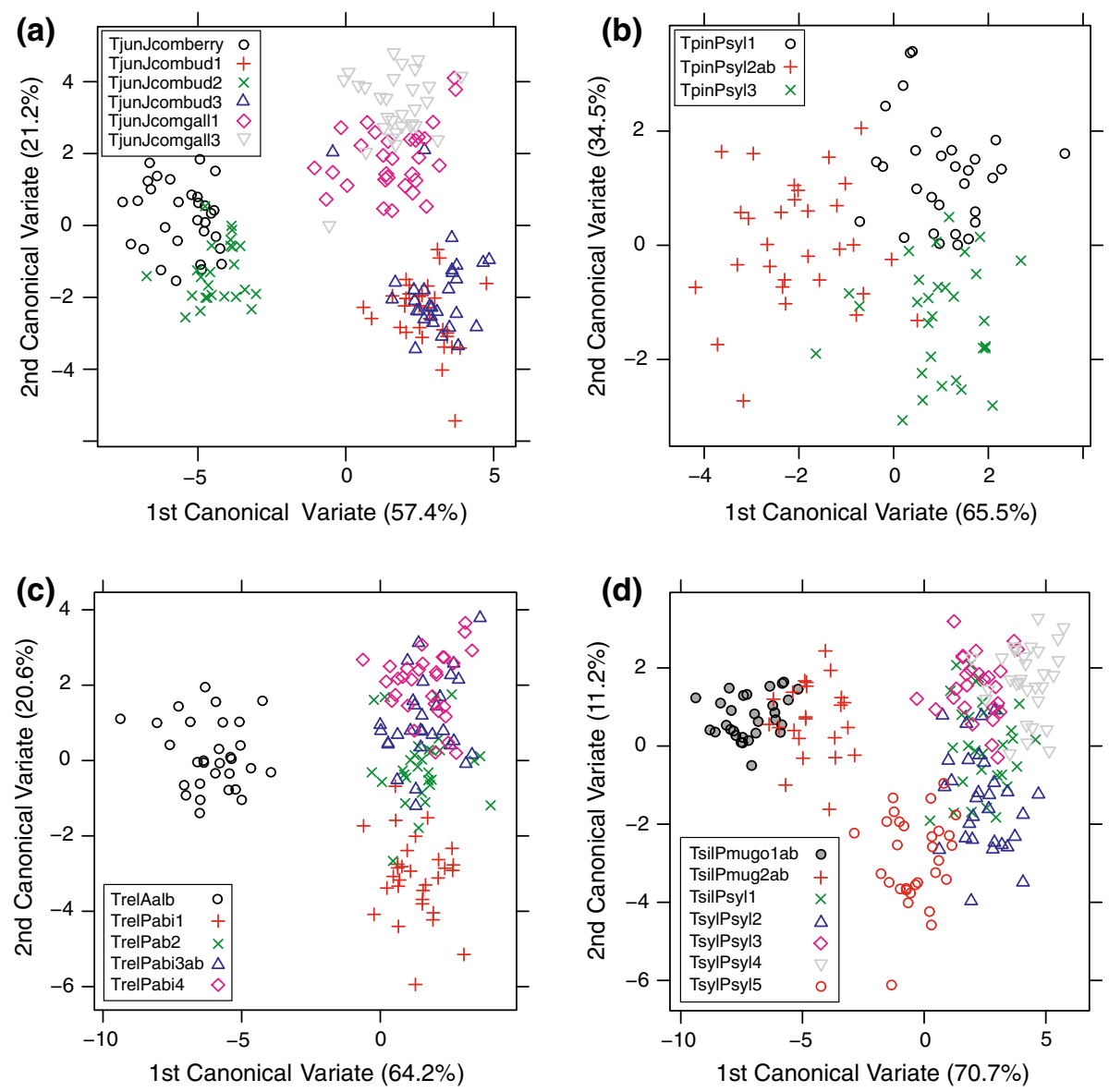

Fig. 5 Individuals of Trisetacus species plotted against their values for two canonical variates that were calculated using traits listed in Fig. 1. a T. juniperinus; b T. pini; c T. relocatus; d T. silvestris. Mite population codes are explained in Table 1

T. pini inferred on the basis of mitochondrial COI sequences were not resolved (polytomy). On the equivalent morphological tree, however, the two Trisetacus species clustered separately. Second, three populations of $T$. pini on the basis of mitochondrial COI sequences formed one clade with low variation (Table 2), but morphologically the population TpinPsyl3 was slightly different from the other two populations. Third, on the mitochondrial COI phylogenetic tree, populations of $T$. silvestris clustered into two hostassociated clades, whereas on the morphological tree one Scots pine population, viz. TsivPsyl5, clustered together with the populations associated with mountain pine. Fourth, on the morphological tree $T$. juniperinus clustered separately from all other species, whereas the other three species showed the following relationships: T. relocatus formed one clade with $T$. silvestris, which was a sister clade to that composed of $T$. pini. On the mitochondrial phylogenetic tree $T$. relocatus formed one unresolved clade with $T$. pini, whereas $T$. silvestris and T. juniperinus clustered in distinct clades (Fig. 6). 
Table 4 First (CV1) and second (CV2) canonical variable loadings for Trisetacus species

\begin{tabular}{|c|c|c|c|c|c|}
\hline \multirow[t]{2}{*}{ Measurement } & \multicolumn{2}{|c|}{ Canonical variable loadings } & \multirow[t]{2}{*}{ Measurement } & \multicolumn{2}{|c|}{ Canonical variable loadings } \\
\hline & CV1 & $\mathrm{CV} 2$ & & CV1 & CV2 \\
\hline \multicolumn{3}{|c|}{ Trisetacus juniperinus } & \multicolumn{3}{|l|}{ Trisetacus pini } \\
\hline K & 1.17 & 0.53 & $\mathrm{~J}$ & -0.97 & -0.01 \\
\hline $\mathrm{E}$ & 0.18 & -0.84 & $\mathrm{~F}$ & 0.04 & -0.56 \\
\hline $\mathrm{J}$ & -0.69 & -0.63 & $\mathrm{C}$ & 0.54 & -0.25 \\
\hline G & -0.57 & -0.08 & S & -0.17 & 0.46 \\
\hline $\mathrm{T}$ & -0.15 & -0.54 & B & 0.07 & -0.44 \\
\hline M & 0.51 & 0.17 & $\mathrm{Z}$ & 0.01 & 0.42 \\
\hline $\mathrm{Z}$ & 0.51 & 0.25 & $\mathrm{X}$ & 0.41 & 0.15 \\
\hline $\mathrm{H}$ & 0.50 & 0.51 & M & 0.15 & -0.41 \\
\hline \multicolumn{3}{|c|}{ Trisetacus relocatus } & \multicolumn{3}{|c|}{ Trisetacus silvestris } \\
\hline $\mathrm{H}$ & -1.43 & -0.63 & $\mathrm{~N}$ & -1.09 & 0.12 \\
\hline V & -1.27 & 0.31 & $\mathrm{H}$ & 0.90 & 0.57 \\
\hline A & 0.67 & 0.74 & B & -0.83 & 0.26 \\
\hline$X$ & -0.61 & 0.73 & A & 0.38 & -0.81 \\
\hline $\mathrm{O}$ & -0.72 & 0.23 & E & -0.60 & 0.43 \\
\hline E & -0.13 & -0.56 & V & -0.51 & 0.44 \\
\hline $\mathrm{T}$ & 0.51 & 0.28 & W & -0.41 & -0.49 \\
\hline $\mathrm{R}$ & 0.45 & -0.03 & $\mathrm{~L}$ & 0.18 & -0.45 \\
\hline
\end{tabular}

See Fig. 1 for abbreviations of measurements
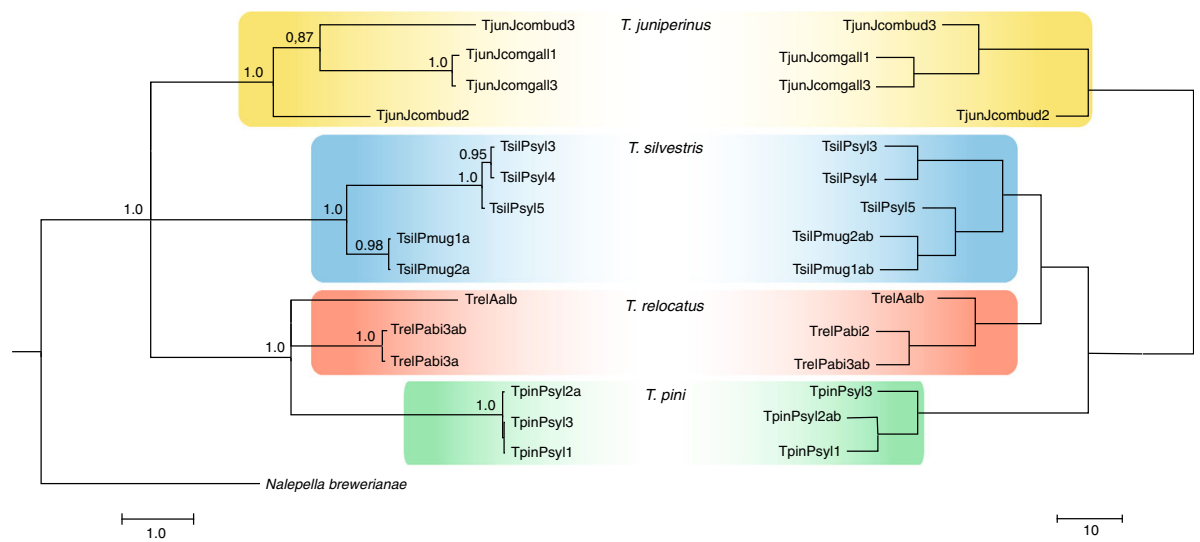

Fig. 6 Comparison of a Bayesian inference (BI) tree (with Bayesian posterior probabilities greater than 0.6 indicated above the branches) of the cytochrome $\mathrm{c}$ oxidase subunit I (only populations for which morphometric data were available are included) (left) with another obtained using Manhattan distance and UPGMA method calculated for morphometric data (right)

\section{Discussion}

DNA-based techniques such as DNA barcoding, i.e. taxon identification through analysis of sequences from standardized DNA regions, has recently received much attention (e.g. 
Hebert et al. 2003; Valentini et al. 2009a, b). Sequences of both mtDNA COI and nuclear D2 as markers for species identification (Hebert et al. 2003; Sonnenberg et al. 2007) were efficient in discriminating between six of the seven Trisetacus species tested in this study, viz. T. silvestris, T. pini, T. quadrisetus, T. juniperinus, T. laricis, and T. piceae. The divergence between these species is comparable to or higher than estimates of interspecific variation in other mite taxonomic groups (e.g. Anderson and Morgan 2007; Dabert et al. 2008; Tixier et al. 2008; Martin et al. 2010; Roy et al. 2010; Skoracka and Dabert 2010; Niedbała and Dabert 2013). Especially high distance values in the D2 region, which is often highly conserved (Lee and O'Foighil 2004), indicate an ancient evolutionary origin of Trisetacus species.

The monophyly of most Trisetacus species studied here, viz. T. pini, T. silvestris, $T$. quadrisetus, T. juniperinus, and T. laricis, was supported. Trisetacus piceae was classified as expected on the basis of COI and D2 but was represented by only one sequence. Thus, to test its monophyly additional samples would need to be sequenced.

In the course of this study, $T$. pini represented a genetic lineage with very low intraclade variation and a morphologically uniform cluster. However, since $T$. pini has been found only on Scots pine in Poland (Skoracka et al. 2005) and we were not able to analyse populations living on other hosts, genetic and morphological differentiation within this species can not be ruled out given that it has also been found on mountain pine, spruce and larch by other researchers (Nalepa 1887, 1911; Shevchenko et al. 1993; Petanović et al. 1996). It is possible that populations of $T$. pini associated with different hosts diverged genetically and morphologically, as it has been already presented for many phytophagous and parasite taxa (e.g. Magalhães et al. 2007; Gwiazdowski et al. 2011; Jorge et al. 2011; Nishimura et al. 2011; Dickey and Medina 2012; Malagnini et al. 2012), including eriophyoid mites (e.g. Skoracka and Dabert 2010; Vidović et al. 2010; Skoracka et al. 2012; Miller et al. 2012, 2013), with T. silvestris (this study) among them.

Trisetacus silvestris so far has been collected only from P. sylvestris in Italy and Poland (Castagnoli 1973; Lewandowski and Kozak 2008; Kozak and Lewandowski 2010). In the course of this study this species was also found on P. mugo. Phylogenetic analyses found $T$. silvestris to be a paraphyletic taxonomic group, with high statistical support for monophyly of two host-associated lineages. Estimates of genetic variation between these two lineages are comparable with inter-specific variation in other mite taxonomic groups (see references above). In addition, morphological analysis supported the divergence of populations living on Scots pine and mountain pine. Similarly, considerable variation was detected within $T$. juniperinus, associated with habitat specialization. Gall-associated populations diverged as a morphologically uniform cluster as well as monophyletic lineage with a large genetic distance from bud-associated populations. These morphological, genetic, physiological and ecological differences between lineages suggest the existence of host-specialized races or even cryptic species within both of these Trisetacus species. It is known that host-association or habitat-association may act as a prezygotic ecological barrier of gene flow and lead to genetic differentiation (Schluter 2001; Kassen 2002). Host- and habitat-induced specialization is very common in parasitic and phytophagous taxa, e.g. avian feather lice (Johnson et al. 2012), malaria parasites (Loiseau et al. 2012), parasitic flatworms (Brooks and McLennan 1993), an acanthocephalan parasite (Steinauer et al. 2007), fleas (Arbiv et al. 2012), beetles (Blair et al. 2005), parasitoid wasps (Kankare et al. 2005), many phytophagous insects (Stireman et al. 2005), and other eriophyoid mites (Miller et al. 2013).

Although gall-associated populations of $T$. juniperinus are suspected to be cryptic species, bud-associated populations of this species exhibited high intra-clade genetic and 
morphological variation. Two bud populations were morphologically similar to each other, whereas one was closer to a berry-associated population. We were not able to obtain DNA material from specimens inhabiting berries, thus any conclusions explaining the genetic relationships between these three populations, differing in their microhabitats, are not available at this time.

Trisetacus relocatus was the only species for which the monophyly was not detected. Two host-associated populations of this species were morphologically and genetically distinct. It is possible that fir- and spruce-associated populations of T. relocatus are two different species. Moreover, the fir-associated population was genetically more related to larch-associated $T$. laricis than to spruce-associated populations of the same species. The relationships between two populations of $T$. relocatus and $T$. laricis do not reflect the host phylogeny, since Larix (larch) is phylogenetically closer to Picea (spruce) (subfamily Pinoideae) than to Abies (fir) (subfamily Abietoideae) (Wang et al. 1999; Gernandt et al. 2008; Christenhusz et al. 2011). Similarly, the phylogenies of other Trisetacus species in this study (Figs. 2, 3, 4, 6) do not reflect host phylogeny, which may suggest that these Trisetacus lineages did not co-evolve with their hosts, rather some host-switching might have occurred (Poulin 2007). On the other hand, the split between Pinoideae and Abietoideae is estimated to have happened in the Jurassic or Early Cretaceous period (Gernandt et al. 2008), whereas eriophyoid fossils in amber have been found in the Triassic period (Schmidt et al. 2012). Thus, the co-evolution of these Trisetacus lineages with their hosts is certainly a possibility. To differentiate between these scenarios it would be necessary to make a wider cross-sampling of Trisetacus species relative to their world distribution and to their host ranges, and to employ additional molecular tools.

It is clear that proper identification of species, especially cryptic species, is important not only for taxonomy and systematics, but also for applied research, particularly in the case of economically important organisms (Navajas and Navia 2010; Hoy 2011; Benefer et al. 2013; Navia et al. 2013), like Trisetacus species. Among the Trisetacus species in this study, there are some that may be harmful to their coniferous hosts. For example, T. pini causes galls on pine twigs, and the large number of galls can decrease the development of young pine or lead to the death of branches of adult trees (Kruel 1963; Shevchenko et al. 1993; Castagnoli et al. 2010). Trisetacus laricis and T. piceae can live inside buds leading to their death or may inhibit development of shoots (Roivainen 1951; Smith 1979; Kadono 1981; Bagnyuk 1984). Trisetacus relocatus inhabits the bases of the current year's shoots and may hamper their development (Bagnyuk and Shevtchenko 1982). The existence of host- and habitat-associated races or species within Trisetacus species raises questions about biological and ecological differences between them. It has been frequently shown that races or species within complexes may differ for traits such as effect on hostplant physiology, pesticide resistance, invasiveness potential, and capacity for agricultural damage (e.g. Dres and Mallet 2002; Umina et al. 2004; de Barro et al. 2011; Navia et al. 2013). Thus, extending our knowledge on biology and diversity of eriophyoid mites is essential for further development of effective plant protection and management strategies.

The broader sampling of Trisetacus species throughout their host and geographical ranges as well as estimation of their DNA diversity on the basis of additional marker loci will be necessary to clarify phylogeny of this genus and seek additional cryptic diversity associated with host- and habitat-specialization. The findings presented here can be an influential contribution to further studies on the phylogeny and systematics of Trisetacus as well as the entire Phytoptidae family. 
Acknowledgments We are grateful to Brian Rector (USDA-ARS, Great Basin Rangelands Research Unit, USA) and Marites A. Sales (Department of Animal Science, University of Arkansas, USA) for linguistic correction and helpful remarks. The study components conducted by AS and WS were supported by the Faculty of Biology, Adam Mickiewicz University, Poznań, Poland. The components conducted by ML was supported financially by the Polish Ministry of Science and Higher Education, Grant No. N309 003 32/0554.

Authors' contributions Mariusz Lewandowski and Anna Skoracka conceived and designed the study. Mariusz Lewandowski collected and identified the material. Wiktoria Szydło and Anna Skoracka genotyped material and analysed molecular data. Mariusz Lewandowski and Tobiasz Druciarek took measurements. Marcin Kozak analysed morphological data. Anna Skoracka and Mariusz Lewandowski wrote the manuscript with assistance from Wiktoria Szydło, Marcin Kozak and Don A. Griffiths. The final manuscript was read and approved by all authors

Open Access This article is distributed under the terms of the Creative Commons Attribution License which permits any use, distribution, and reproduction in any medium, provided the original author(s) and the source are credited.

\section{References}

Amrine JW Jr, Manson DCM (1996) Preparation, mounting and descriptive study of eriophyoid mites. In: Lindquist EE, Sabelis MW, Bruin J (eds) Eriophyoid mites-their biology, natural enemies and control (World Crop Pests). Elsevier Science, Amsterdam, pp 383-396

Amrine JW Jr, Stasny TAH, Flechtmann CHW (2003) Revised keys to the world genera of the Eriophyoidea (Acari: Prostigmata). Indira Publishing House, West Bloomfield

Anderson DL, Morgan MJ (2007) Genetic and morphological variation of bee-parasitic Tropilaelaps mites (Acari: laelapidae): new and re-defned species. Exp Appl Acarol 43:1-24. doi:10.1007/s10493-0079103-0

Anisimova M, Gascuel O (2006) Approximate likelihood-ratio test for branches: a fast, accurate, and powerful alternative. Sys Biol 55:539-552

Arbiv A, Khokhlova IS, Ovadia O, Novoplansky A, Krasnov BR (2012) Use it or lose it: reproductive implications of ecological specialization in a haematophagous ectoparasite. J Evolution Biol 25: $1140-1148$

Armstrong KF, Ball SL (2005) DNA barcodes for biosecurity: invasive species identification. Philos Trans R Soc Lond B 360:1813-1823. doi:10.1098/rstb.2005.1713

Bagnyuk IG (1976) Cetyrechnogij klesc Trisetacus piceae (Roiv.) (Acarina: Eriophyoidea)—vreditel pocek jeli obuknovenno. [The eriophyid mite,Trisetacus piceae (Roiv.) (Acarina, Eriophyoidea)—Pest of Norway Spruce.] Trudy Petergof Biol Inst 24:130-145

Bagnyuk IG (1984) Novii chetirekhnogii kleshch (Acarina, Tetrapodili) iz pochek pikhti sibirskoi. [A new bud mite (Acarina, Tetrapodili) the pest of the Siberian fir (Abies sibirica)]. Zool Zh 63:373-381

Bagnyuk IG, Shevtchenko VG (1982) [A new species of mite of the genus Trisetacus Keifer (Acarina, Tetrapodili) on spruce, Picea abies (L.) Karst.] Entomol Obozr 41:195-200 (Entomol Rev 61:189-194)

Benefer CM, van Herk WG, Ellis JS, Blackshaw RP, Vernon RS, Knight ME (2013) The molecular identification and genetic diversity of economically important wireworm species (Coleoptera: elateridae) in Canada. J Pest Sci 86:19-27

Benson DA, Karsch-Mizrachi I, Lipman DJ, Ostell J, Wheeler DL (2005) GenBank. Nucleic Acids Res 33:D34-D38. doi:10.1093/nar/gki063

Bickford D, Lohman DJ, Sodhi NS, Ng PKL, Meier R, Winker K, Ingram KK, Das I (2007) Cryptic species as a window on diversity and conservation. Trend Ecol Evol 22:148-155. doi:10.1016/j.tree.2006.11.004

Blair CP, Abrahamson WG, Jackman JA, Tyrrell L (2005) Cryptic speciation and host-race formation in a purportedly generalist tumbling flower beetle. Evolution 59:304-316

Boczek J, Shevchenko VG (1996) Ancient associations: eriophyoid mites and gymnosperms. In: Lindquist EE, Sabelis MW, Bruin J (eds) Eriophyoid mites - their biology, natural enemies and control (World Crop Pests). Elsevier Science, Amsterdam, pp 217-225

Bouneb M, de Lillo E, Roversi PF, Simoni S (2014) Molecular detection assay of the bud mite Trisetacus juniperinus on Cupressus sempervirens in nurseries of central Italy. Exp Appl Acarol 62:161-170. doi:10.1007/s10493-013-9733-3

Brooks DR, McLennan DA (1993) Macroevolutionary patterns of morphological diversification among parasitic flatworms (Platyhelmithes, Cercomeria). Evolution 47:495-509 
Carew ME, Goodisman MAD, Hoffmann AA (2004) Species status and population genetic structure of grapevine eriophyoid mites. Entomol Exp Appl 111(2):87-96

Carew M, Schiffer M, Umina P, Weeks A, Hoffmann A (2009) Molecular markers indicate that the wheat curl mite, Aceria tosichella Keifer, may be a species complex in Australia. Bull Entomol Res 99:479-486. doi:10.1017/S0007485308006512

Castagnoli M (1973) Contributo alla conoscenza degli acari Eriofidi viventi sul gen. Pinus in Italia. Redia $54: 1-22$

Castagnoli M (1996) Ornamental coniferous and shade trees. In: Lindquist EE, Sabelis MW, Bruin J (eds) Eriophyoid mites-their biology, natural enemies and control (World Crop Pests). Elsevier Science, Amsterdam, pp 661-671

Castagnoli M, Lewandowski M, Łabanowski GS, Simoni S, Soika GM (2010) An insight into some relevant aspects concerning eriophyoid mites inhabiting forests, ornamental trees and shrubs. Exp Appl Acarol 51:169-189. doi:10.1007/s10493-009-9313-8

Christenhusz MJM, Reveal JL, Farjon A, Martin F, Gardner MF, Robert R, Mill RR, Chase MW (2011) A new classification and linear sequence of extant gymnosperms. Phytotaxa 19:55-70

Dabert J, Ehrnsberger R, Dabert M (2008) Glaucalges tytonis sp. n. (Analgoidea, Xolalgidae) from the barn owl Tyto alba (Strigiformes, Tytonidae): compiling morphology with DNA barcode data for taxon descriptions in mites (Acari). Zootaxa 1719:41-52

Darriba D, Taboada GL, Doallo R, Posada D (2012) jModelTest 2: more models, new heuristics and parallel computing. Nat Methods 9(8):772

de Barro PJ, Liu SS, Boykin LM, Dinsdale AB (2011) Bemisia tabaci: a statement of species status. Annu Rev Entomol 56:1-19. doi:10.1146/annurev-ento-112408-085504

de Lillo E, Skoracka A (2010) What's “cool” on eriophyoid mites? Exp Appl Acarol 51:3-30. doi:10.1007/ s10493-009-9297-4

de Lillo E, Craemer C, Amrine JW Jr, Nuzzaci G (2010) Recommended procedures and techniques for morphological studies of Eriophyoidea (Acari: prostigmata). Exp Appl Acarol 51:283-307. doi:10. 1007/s10493-009-9311-x

Dickey AM, Medina RF (2012) Host-associated genetic differentiation in pecan leaf phylloxera. Entomol Exp Appl 143:127-137. doi:10.1111/j.1570-7458.2012.01250.x

Dres M, Mallet J (2002) Host races in plant-feeding insects and their importance in sympatric speciation. Philos Trans R Soc Lond B Biol Sci 357:471-492

Fenton B, Jones AT, Malloch G, Thomas WP (1996) Molecular ecology of some Cecidophyopsis mites (Acari: eriophyidae) on Ribes species and evidence for their natural cross colonisation of blackcurrant (R. nigrum). Ann Appl Biol 128:405-414

Fenton B, Malloch G, Moxey E (1997) Analysis of eriophyid mite rDNA internal transcribed spacer sequences reveals variable simple sequence repeats. Insect Mol Biol 6:23-32

Fenton B, Birch ANE, Malloch G, Lanham PG, Brennan RM (2000) Gall mite molecular phylogeny and its relationship to the evolution of plant host specificity. Exp Appl Acarol 24:831-861

Futuyma DJ, Moreno G (1988) The evolution of ecological specialization. Annu Rev Ecol Syst 19:207-233

Gernandt DS, Magallón S, Lopez GG, Flores OZ, Willyard A, Liston A (2008) Use of simultaneous analyses to guide fossilbased calibrations of Pinaceae phylogeny. Int J Plant Sci 169:1086-1099

Goolsby JA, de Barro PJ, Makinson JR, Pemberton RW, Hartley DM, Frohlich DR (2006) Matching the origin of an invasive weed for selection of a herbivore haplotype for a biological control programme. Mol Ecol 15:287-297

Guindon S, Gascuel O (2003) A simple, fast, and accurate algorithm to estimate large phylogenies by maximum likelihood. Sys Biol 52:696-704

Guindon S, Dufayard JF, Lefort V, Anisimova M, Hordijk W, Gascuel O (2010) New algorithms and methods to estimate Maximum-likelihood phylogenies: assessing the performance of PhyML 3.0. Syst Biol 59:307-321

Gwiazdowski RA, Vea IM, Andersen JC, Normark BB (2011) Discovery of cryptic species among North American pine-feeding Chionaspis scale insects (Hemiptera: diaspididae). Biol J Linn Soc 104:47-62. doi:10.1111/j.1095-8312.2011.01716.x

Hasegawa M, Kishino H, Yano T (1985) Dating of the human-ape splitting by a 757 molecular clock of mitochondrial DNA. J Mol Evol 22:160-174

Hebert PDN, Ratnasingham S, de Waard JR (2003) Barcoding animal life: cytochrome $c$ oxidase subunit 1 divergences among closely related species. Proc R Soc Lond B 270:S96-S99

Hebert PDN, Penton EH, Burns JM, Janzen DH, Hallwachs W (2004) Ten species in one: DNA barcoding reveals cryptic species in the neotropical skipper butterfly Astraptes fulgerator. PNAS 101:14812-14817. doi:10.1073/pnas.0406166101 
Hong X-Y, Zhang Z-Q (1996a) A cladistic analysis of the Eriophyoidea (Acari: prostigmata): tests of monophyly of families. Syst Appl Acarol 1:107-122

Hong X-Y, Zhang Z-Q (1996b) A phylogenetic study of the tribe Cecidophyini Keifer (Acari: Eriophyidae). Orient Insects 30:279-300. doi:10.1080/00305316.1996.10434104

Hong X-Y, Zhang Z-Q (1997) Systematics and generic relationships of the mites in the subfamily Diptilomiopinae (Acari: Eriophyoidea: Diptilomiopidae). Syst Entomol 22:313-331. doi:10.1046/j.13653113.1997.d01-48.x

Hoy MA (2011) Pest mites and their natural enemies on plants. In: Hoy MA (ed) Agricultural acarology: introduction to integrated mite management. CRC Press, Boca Raton, pp 83-121

Jeppson LR, Keifer HH, Baker EW (1975) Mites injurious to economic plants. University of California Press, Berkeley

Johnson KP, Shreve SM, Smith VS (2012) Repeated adaptive divergence of microhabitat specialization in avian feather lice. BMC Biol 10:52. doi:10.1186/1741-7007-10-52

Jorge LR, Cordeiro-Estrela P, Klaczko LB, Moreira GRP, Freitas AVL (2011) Host-plant dependent wing phenotypic variation in the neotropical butterfly Heliconius erato. Biol J Linn Soc 102:765-774. doi:10.1111/j.1095-8312.2010.01610.x

Kadono F (1981) Two new eriophyid mites from Japan (Acarina, Eriophyidae). Appl Ent Zool 16:419-422

Kankare M, Constantí S, Van Nouhuys S, Shaw MR (2005) Host specialization by Cotesia wasps (Hymenoptera: Braconidae) parasitizing species-rich Melitaeini (Lepidoptera: Nymphalidae) communities in north-eastern Spain. Biol J Linn Soc 86:45-65

Kassen R (2002) The experimental evolution of specialists, generalists, and the maintenance of diversity. J Evol Biol 15:173-190

Kaufman L, Rousseeuw PJ (1990) Finding groups in data: an introduction to cluster analysis. Wiley, New York

Keifer HH, Saunders JL (1972) Trisetacus campnodus n. sp. (Acarina: Eriophyidae) attacking Pinus sylvestris. Ann Entomol Soc Amer 65:46-49

Keifer HH, Baker EW, Kono T, Delfinado M, Styer WE (1982) An illustrated guide to plant abnormalities caused by Eriophyid mites in North America. USDA, Agriculture Handbook 573

Kimura M (1981) Estimation of evolutionary distances between homologous nucleotide sequences. Proc Natl Acad Sci USA 78:454-458

Kozak M, Lewandowski M (2010) Eriophyoid mites (Acari: Eriophyoidea) on coniferous trees: is the occurrence of one species associated with the other? Exp Appl Acarol 50:115-122. doi:10.1007/ s10493-009-9291-x

Kruel W (1963) Gallmilben an Kiefer (Acarina: Eriophyidae). Beitr Ent 13:566-576

Krzanowski WJ (2000) Principles of multivariate analysis-a user's perspective. Oxford University Press, Oxford

Kumar PL, Fenton B, Jones AT (1999) Identification of Cecidophyopsis mites (Acari: Eriophyidae) based on variable simple sequence repeats of ribosomal DNA internal transcribed spacer-1 sequences via multiplex PCR. Insect Mol Biol 8:347-357

Kumar PL, Fenton B, Duncan GH, Jones AT, Sreenivasulu P, Reddy DVR (2001) Assessment of variation in Aceria cajani using analysis of rDNA ITS regions and scanning electron microscopy: implications for the variability observed in host plant resistance to pigeonpea sterility mosaic disease. Ann Appl Biol 139:61-73

Łabanowski G, Soika G (2000) Eriophyoid mites (Acari: Eriophyoidea) on ornamental coniferous plants in Poland. J Plant Prot Res 40:85-93

Lee T, O'Foighil D (2004) Hidden Floridian biodiversity: mitochondrial and nuclear gene trees reveal four cryptic species within the scorched mussel, Brachidontes exustus, species complex. Mol Ecol 13:3527-3542. doi:10.1111/j.1365-294X.2004.02337.x

Lemmetty A, Tikkanen M, Tuovinen T, Lehto K (2004) Identification of different Cecidophyopsis mites on Ribes in Finland. Acta Horticult 656:115-118

Lewandowski M, Kozak M (2008) Distribution of eriophyoid mites (Acari: Eriophyoidea) on coniferous trees. Exp Appl Acarol 44:89-99. doi:10.1007/s10493-008-9135-0

Lindquist EE (1996) Nomenclatorial problems in usage of some family and genus names. In: Lindquist EE, Sabelis MW, Bruin J (eds) Eriophyoid mites - their biology, natural enemies and control (World Crop Pests). Elsevier Science, Amsterdam, pp 89-99

Lindquist EE, Amrine JW Jr (1996) Systematics, diagnoses for major taxa, and keys to families and genera with species on plants of economic importance. In: Lindquist EE, Sabelis MW, Bruin J (eds) Eriophyoid mites - their biology, natural enemies and control (World Crop Pests). Elsevier Science, Amsterdam, pp 33-87 
Loiseau C, Harrigan RJ, Robert A, Bowie RCK, Thomassen HA, Smith TB, Sehgal RNM (2012) Host and habitat specialization of avian malaria in Africa. Mol Ecol 21:431-441. doi:10.1111/j.1365294X.2011. 05341.x

Magalhães S, Forbes MR, Skoracka A, Osakabe M, Chevillon C, McCoy KD (2007) Host race formation in the Acari. Exp Appl Acarol 42:225-238. doi:10.1007/s10493-007-9091-0

Magud B, Stanisavljević LJ, Petanović R (2007) Morphological variation in different populations of Aceria anthocoptes (Acari: Eriophyoidea) associated with the Canada thistle, Cirsium arvense, in Serbia. Exp Appl Acarol 42:173-183

Malagnini V, Navajas M, Migeon A, Duso C (2012) Differences between sympatric populations of Eotetranychus carpini collected from Vitis vinifera and Carpinus betulus: Insights from host-switch experiments and molecular data. Exp Appl Acarol 56:209-219. doi:10.1007/s10493-012-9511-7

Marshall VG, Clayton MR (2004) Biology and phenology of Cecidophyopsis psilaspis (Acari: Eriophyidae) on Pacific yew (Taxaceae). Can Entomol 136:695-710

Martin P, Dabert M, Dabert J (2010) Molecular evidence for species separation in the water mite Hygrobates nigromaculatus Lebert, 1879 (Acari, Hydrachnidia): evolutionary consequences of the loss of larval parasitism. Aquat Sci 72:347-360

Miller AD, Umina PA, Weeks AR, Hoffmann AA (2012) Population genetics of the wheat curl mite (Aceria tosichella Keifer) in Australia: implications for the management of wheat pathogens. Bull Entomol Res 102:199-212

Miller AD, Skoracka A, de Mendonca RS, Szydło W, Schultz MB, Smith CM, Truol G, Hoffmann AA (2013) Phylogenetic analyses reveal extensive cryptic speciation and host specialization in an economically important mite taxon. Mol Phylogenet Evol 66:928-940. doi:10.1016/j.ympev.2012.11.021

Mironov SV, Dabert J, Dabert M (2012) A new feather mite species of the genus Proctophyllodes Robin, 1877 (Astigmata: Proctophyllodidae) from the Long-tailed Tit Aegithalos caudatus (Passeriformes: Aegithalidae - morphological description with DNA barcode data. Zootaxa 3253:54-61

Nalepa A (1887) Die Anatomie der Phytopten. Sitzb kaiser Akad Wiss Math-Nat. Wien 96(4):115-165

Nalepa A (1911) Eriophyiden. Gallenmilben. Zoologica 24(61):166-293

Navajas M, Fenton B (2000) The application of molecular markers in the study of diversity in acarology: a review. Exp Appl Acarol 24:751-774

Navajas M, Navia D (2010) DNA-basedmethods for eriophyoidmite studies: review, critical aspects, prospects and challenges. Exp Appl Acarol 51:257-271. doi:10.1007/s10493-009-9301-Z

Navia D, de Moraes GJ, Roderick G, Navajas M (2005) The invasive coconut mite Aceria guerreronis (Acari: Eriophyidae): origin and invasion sources inferred from mitochondrial (16S) and nuclear (ITS) sequences. Bull Entomol Res 95:505-516

Navia D, de Moraes GJ, Querino RB (2006) Geographic variation in the coconut mite, Aceria guerreronis Keifer (Acari: Eriophyidae): a geometric morphometric analysis. Int J Acarol 32:301-314. doi:10. 1080/01647950608684473

Navia D, Mendonça RS, Ferragut F, Miranda LC, Trincado RC, Michaux J, Navajas M (2013) Cryptic diversity in Brevipalpus mites (Tenuipalpidae). Zool Scripta 42:406-426. doi:10.1111/zsc.1201

Niedbała W, Dabert M (2013) Madeira's ptyctimous mites (Acari, Oribatida). Zootaxa 3664:571-585

Nishimura N, Heins DC, Andersen RO, Barber I, Cresko WA (2011) Distinct lineages of schistocephalus parasites in threespine and ninespine Stickleback hosts revealed by DNA sequence analysis. PLoS ONE 6(7):e22505. doi:10.1371/journal.pone.0022505

Petanović R, Boczek J, Jovanović S, Stojnić B (1996) [Eriophyoidea (Acari: Prostigmata) Fauna Durmitora, 5] (in Serbian). CANU, Posebna izdanja, knjiga 32, Odjeljenje prirodnih nauka, knjiga 18, Podgorica

Posada D (2003) Using MODELTEST and PAUP* to select a model of nucleotide substitution. Curr Protoc Bioinf. Chapter 6: Unit 6.5. doi: 10.1002/0471250953.bi0605s00

Posada D (2008) jModelTest: phylogenetic model averaging. Mol Biol Evol 25:1253-1256. doi:10.1093/ molbev/msn083

Poulin R (2007) Evolutionary ecology of parasites, 2nd edn. Princeton University Press, Princeton

Pringle A, Baker DM, Platt JL, Wares JP, Latge JP, Taylor JW (2005) Cryptic speciation in the cosmopolitan and clonal human pathogenic fungus Aspergillus fumigatus. Evolution 59:1886-1899

R Development Core Team (2013) R: a language and environment for statistical computing. R Foundation for Statistical Computing, Vienna, Austria. ISBN 3-900051-07-0, URL http://www.R-project.org. Accessed 03 Sept 2013

Rodriguez F, Oliver JF, Marín A, Medina JR (1990) The general stochastic model of nucleotide substitution. J Theor Biol 142:485-501

Roivainen H (1951) Contributions to the knowledge of the eriophyids of Finland. Acta Entomol Fenn 8:1-72 
Ronquist F, Teslenko M, van der Mark P, Ayres DL, Darling A, Höhna S, Larget B, Liu L, Suchard MA, Huelsenbeck JP (2012) MrBayes 3.2: efficient Bayesian phylogenetic inference and model choice across a large model space. Syst Biol 61:539-542. doi:10.1093/sysbio/sys029

Roy L, Dowling APG, Chauve CM, Buronfosse T (2010) Diversity of phylogenetic information according to the locus and the taxonomic level: an example from a parasitic mesostigmatid mite genus. Int J Mol Sci 11:1704-1734. doi:10.3390/ijms11041704

Schluter D (2001) Ecology and the origin of species. Trends Ecol Evol 16:372-380

Schmidt AR, Jancke S, Lindquis EE, Ragazzi E, Roghi G, Nascimbene PC, Schmidt K, Wappler T, Grimaldi DA (2012) Arthropods in amber from the Triassic Period. PNAS 109:14796-14801

Shevchenko VG (1962) Novii chetirekhnogij Kleshch Trisetacus kirghizorum sp.n. (Acarina, Eriophyidae) vreditel semjan arci. Tr Kirgh Lesn Opytn Sta 3:299-305

Shevchenko VG (1995) On phototaxis in two species of genus Trisetacus (Acari: Eriophyoidea). In: Boczek J, Ignatowicz S (eds) Proceedings on symposium "advances of acarology in Poland”, Siedlice, pp 77-83

Shevchenko VG, Bagnyuk IG, Rinne V (1993) Trisetacus pini (Nalepa, 1889) in some Baltic countries and in Russia (Taxonomy, morphology, biology, distribution). Acarina 1:51-71

Simoni S, Cantini R, Castagnoli M, Battisti A (2004) Impact and management of the eriophyoid mite Trisetacus juniperinus on the evergreen cypress Cupressus sempervirens. Agric For Entomol 6:175-180. doi:10.1111/j.1461-9555.2004.00223.x

Skoracka A, Dabert M (2010) The cereal rust mite Abacarus hystrix (Acari: Eriophyoidea) is a complex of species: evidence from mitochondrial and nuclear DNA sequences. Bull Entomol Res 100:263-272. doi: $10.1017 /$ S0007485309990216

Skoracka A, Kuczyński L (2006) Infestation parameters and morphological variation of the wheat curl mite Aceria tosichella Keifer (Acari: Eriophyoidea). In: Ignatowicz S, Gabryś G (eds) Advances in Polish acarology. SGGW, Warszawa, pp 330-339

Skoracka A, Kuczyński L, Magowski W (2002) Morphological variation in different host populations of Abacarus hystrix (Acari: Prostigmata: Eriophyoidea). Exp Appl Acarol 26:187-193

Skoracka A, Lewandowski M, Boczek J (2005) A catalogue of eriophyoid mites (Acari: Eriophyoidea) of Poland. Catalogus faunae Poloniae, Muzeum i Instytut Zoologii PAN, Warszawa

Skoracka A, Kuczyński L, de Mendonca RS, Dabert M, Szydło W, Knihinicki D, Truol G, Navia D (2012) Cryptic species within the wheat curl mite Aceria tosichella (Keifer) (Acari, Eriophyoidea) revealed by mitochondrial, nuclear and morphometric data. Invertebr Syst 26:417-433

Skoracka A, Kuczyński L, Szydło W, Rector B (2013) The wheat curl mite Aceria tosichella (Acari: Eriophyoidea) is a complex of cryptic lineages with divergent host ranges: evidence from molecular and plant bioassay data. Biol J Linn Soc 109:165-180. doi:10.1111/bij.12024

Skoracka A, Kuczyński L, Rector B, Amrine J (2014) Wheat curl mite and dry bulb mite: untangling a taxonomic conundrum through a multidisciplinary approach. Biol J Linn Soc 111:421-436. doi:10. 1111/bij.12213

Smith IM (1979) Description of new species of Trisetacus (Prostigmata, Eriophyoidea) from Pinaceae in Eastern North America. Can Entomol 111:425-429

Smith IM (1984) Review of species of Trisetacus (Acari: Eriophyoidea) from North America, with comments on all nominate taxa in the genus. Can Entomol 116:1157-1211

Sonnenberg R, Nolte AW, Tautz D (2007) An evaluation of LSU rDNA D1-D2 sequences for their use in species identification. Front Zool 4:6. doi:10.1186/1742-9994-4-6

Steinauer ML, Nickol BB, Ortí G (2007) Cryptic speciation and patterns of phenotypic variation of a highly variable acanthocephalan parasite. Mol Ecol 16:4097-4109. doi:10.1111/j.1365-294X.2007.03462.X

Stireman JO III, Nason JD, Heard SB (2005) Host associated genetic differentiation in phytophagous insects: general phenomenon or isolated exceptions? Evidence from a goldenrod-insect community. Evolution 59:2573-2587

Styer WE, Nielsen D, Balderston CP (1972) A new species of Trisetacus (Acarina: Eriophyoidea: Nalepellidae) from Scotch pine. Ann Entomol Soc Amer 65:1089-1091

Tamura K, Peterson D, Peterson N, Stecher G, Nei M, Kumar S (2011) MEGA5: molecular evolutionary genetics analysis using maximum likelihood, evolutionary distance, and maximum parsimony methods. Mol Biol Evol 28:2731-2739. doi:10.1093/molbev/msr121

Tixier MS, Kreiter S, Croft BA, Cheval B (2008) Kampimodromus aberrans (Acari: Phytoseiidae) from the USA: morphological and molecular assessment of its density. Bull Entomol Res 98:125-134. doi:10. 1603/0046-225X-31.4.648

Tubeuf C (1897) Phytoptus laricis n.sp., ein neuer Parasit der Larche. Larix europaea. Forstl Z Muenchen 6:120-124

Umina PA, Hoffmann AA, Weeks AR (2004) Biology, ecology and control of the Penthaleus species complex (Acari: Penthaleidae). Exp Appl Acarol 34:211-237 
Valentini A, Pompanon F, Taberlet P (2009a) DNA barcoding for ecologists. Trends Ecol Evol 24:110-117 Valentini A, Miquel C, Nawaz MA, Bellemain E, Coissac E et al (2009b) New perspectives in diet analysis based on DNA barcoding and parallel pyrosequencing: the trnL approach. Mol Ecol Resour 9:51-60

Venables WN, Ripley BD (2002) Modern applied statistics with S, 4th edn. Springer, New York

Vidović B, Stanisavljević L, Petanović R (2010) Phenotypic variability in five Aceria spp. (Acari: Prostigmata: Eriophyoidea) inhabiting Cirsium species (Asteraceae) in Serbia. Exp Appl Acarol 52:169-181. doi:10.1007/s10493-010-9354-Z

Wang X-R, Tsumura Y, Yoshimaru H, Nagasaka K, Szmidt AE (1999) Phylogenetic relationships of Eurasian pines (Pinus, Pinaceae) based on chloroplast $r b c l$, matK, rpl20-rps 18 spacer, and trnV intron sequences. Am J Bot 86:1742-1753

Wang G-Q, Wei S-G, Yang D (2012) Three new species of eriophyoid mites from China (Acari: Eriophyoidea). Int J Acarol 38:244-250. doi:10.1080/01647954.2011.633557

Ward LK, Hackshaw A, Clarke R (2003) Do food-plant preferences of modern families of phytophagous insects and mites reflect past evolution with plants? Biol J Linn Soc 78:51-83

Xue X-F, Song Z-W, Amrine JW, Hong X-Y (2007) Eriophyoid mites on coniferous plants in China with descriptions of a new genus and five new species (Acari: Eriophyoidea). Int J Acarol 33:333-345. doi:10.1080/01647950708683695 